\title{
A Study on Consumer Behaviour Towards Purchase of Select Instant Packed Food Products in Cuddalore District
}

\author{
M. Akila and K. Ramesh \\ $P G$ \& Research Department of Commerce Marudupandiyar \\ College Thanjavur- 613 403, India
}

\section{ABSTRACT}

Consumer behaviour refers to the behavior that consumers display in searching for, purchasing using, evaluating and disposing the products and services. Consumer behavior is important in helping to forecast and understand for products as well as brand preference. The present paper highlights the study of consumer behavior regarding instant food products among the consumers. The most dramatic change is the change in consumer demographics and demand preferences. Hence, an attempt has been made to analyse the consumer purchasing frequency for the instant food products. Further efforts have also been made to know the consumer awareness towards products and to analyse factors affecting the moment food items.

\section{KEY WORDS: CONSUMER BEHAVIOR, DEMOGRAPHIC, INSTANT FOOD PRODUCTS.}

\section{INTRODUCTION}

Food is the first basic need of mankind. It is an essential tool for survival of human race. Food promotes health and is the first basic need for all living creatures. Only when need of the foodgets satisfied man moves in search of other needs. The discovery of fire marked a turning point in the process of civilization and man has learned to cook food. During the course of time, the man changed his food habits according to his taste, experience and availability of food materials and changing sessions of the year. So food is considered to be a symbol of hospitality, social status and ritualistic importance. In the changing socio-domestic scenario, both men and women necessarily have to go for employment to augment the household income. Hence cooking food in conventional method is really an ordeal for women. The modern men and women were hard pressed for time. They have to yield themselves for the fast changing life style which

Biosc Biotech Res Comm P-ISSN: 0974-6455 E-ISSN: 2321-4007

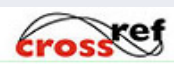

Identifiers and Pagination

Year: 2021 Vol: 14 No (6) Special Issue

Pages: $344-348$

This is an open access article under Creative

Commons License Attribn 4.0 Intl (CC-BY).

DOI: $h t t p: / / d x . d o i . o r g / 10.21786 / b b r c / 14.6 .71$ regards cooking and food habits. The advancement of science and technology offered the people to.

Speed up the cooking process in order to cope up with the mechanical life. This makes Instant packed food to hold the substantial position in the market. Instant food can be termed as "foods that have undergone major processing by the manufacturer, such that they require little or no secondary processing and cooking before consumption. The consumer has certain expectation from Instant packed foods in terms of its quality, price, taste, flavor, package and reputation. Instant packed foods do not contain any chemical preservation and it remains shelf-stable without refrigeration for at least one year, for vegetarian Instant food items. Instant foods have become one more option in the home-meal replaced segment along with the conventional options like restaurants, mess/canteen and catering service. The increasing money spent on advertisement make the consumer to be aware of the latest brands in the market. Instant packed foods are in almost all retail outlets, departmental stores and super markets. People can purchase their brands from such shops. Thus Instant foods offered with several benefits plays a vital role in the lives of many Indian consumers.

Review of Literature: M.Balaswamy et al (2012) in their study have revealed that to analyze the existing buying behaviour of Instant Food Products by individual

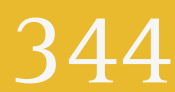


households and to predict the demand for Instant Food Products of Hyderabad city in Andhra Pradesh .The average monthly expenditure on Instant Food Products was found to be highest in higher income groups. The average per capita purchase and per capita expenditure on Instant food Products had a positive relationship with income of households. High price and poor taste were the reasons for not purchasing particular brand whereas best quality, retailers influence and ready availability were considered for preferring particular brand of products by the consumers.

Dr.palaneeswari T et al (2013) examined that the fast moving world,the human beings do not take nutritious food. The study is relevant to present day market condition which is flooded with wide verities of products, which are open to the consumers. An attempt has been made to identify the important factors that influence the purchase of instant cooking food products.To analyse the data collected, statistical tools like percentage and factor analysis were employed.The study reveals that influence of global trade cheap and economical price of fast food and emergency of nuclear family are the main reasons that make the respondents to prefer instant food.

K.Srinivasan and R.Nirmala (2014) in this study on Consumer behaviour refers to the behavior that consumers display in searching for, purchasing using , evaluating and disposing the products and services. Consumer behavior is important in helping to forecast and understand for products as well as brand preference. The present paper highlights the study of consumer behavior regarding instant food products among the consumers. The most dramatic change is the change in consumer demographics and demand preferences. Hence, an attempt has been made to analyse the consumer purchasing frequency for the instant food products. Further efforts have also been made to know the consumer awareness towards products and to analyse factors influencing the instant foodproducts.

A.K.Ramasamyet al (2015) discussed in their study on Energy is required for sustaining all forms of life on earth and so food is the basic need of a man for his survival. The primitive man was largely dependent for his food on fruits and animals. The discovery of fire marked a turning point in the process of civilization and man has learned to cook food. During the course of time, the man changed his food habits according to his taste, experience, and availability of food materials and changing vessels, equipments and tools but still people were in search of new technichques to speed up the cooking process in order to lope up with mechanical life, as they do not have sufficient time cook food in the conventional methods.

So the modern men and women hard pressed for time have to yield themselves to the fast changing life styles as regards cooking and food habits. In the ever changing socio-domestic scenario, both men and women have to necessarily go for employement to augment the household income and cooking food in traditional method is really an ordeal for women. Dr.V.Selvarani and A.Zeenath Amman (2016) discussed in their study with globalization and modernization, the modern competitive business is based on understanding the best products and services that he wants. Considering the truth that the consumer is the king, every organization wants to increase market share and profit . The competitors are also following the same strategy.

It involves the psychological processes that consumers got through in recognizing needs, finding ways to solve these needs, making purchase decisions, interpret information, make plans and implement those plans by engaging in comparison shopping or actually purchasing a product. Consumer behaviour is one of the stimulating and challenging areas in marketing studies being a human activity focused onthe products and services. Understanding the behaviour of the consumers is a great challenge. Tiruchirappalli city were selected based on population as high, medium and low population. The sample size is 85 and the samples selected based on the simple random sampling method. It was found that the average monthly expenditure on Instant Food Products was found to be highest in higher income groups.The average per capita purchase and per capita expenditure on Instant food Products had a positive relationship with income ofhouseholds.

Dr.N.Vijaylakshmi (2019) in this article 'Instant' is the word which is widely spelt by the modern man to indicate the completion of any work quickly and thereby saving time and energy. The ever changing life style of modern man comples him to search for such commodities which can give him better satisfaction in the changing circumstances of his life style. Among the products,"Instant cooking products"(ICFPS)offered by modern business units have revolutionized the day to day life modern men by eliminating conventional method of preparing food.The emergence of metropolitan cities,reduced domestic servents, women-folk talking to jobs,increase in the nuclear families, heavy laborious work like grinding manually and other grudging works involved in conventional method of cooking etc,are the factors responsible for the popularity of these products. These articles studys about consumer behaviour towards instant cooking food products in Madurai district,Tamilnadu.

Statement of the problem: The eating habits of the people are changing; home-made meals were often replaced by food items bought from outside. But in with the nuclear family there seems to be a shift for the housewife's attitude to cooking and the meals she serves. Then theteenagerswere becoming influencedto change the meal patterns in family. More than that the average Indian is now spending money more liberally than before.Food and drink acquires a greater 'fun' of image for him than before. Finally, these changes in attitude primarily cause the growth of fast foods and convenient foods. Even among the low income households there is also a substantial change in the aspiration levels. In thiscontext, the researcher wants to undertake the study 
on consumer behaviour towards purchase of instant packed food products.

\section{Objectives of the study}

1. To identify the awareness of respondents about the instant packed food products.

2. To find out the factors that influences the purchase of packed food products.

3. To study the consumer, opinions and preferences towards purchase of instant packed food products.

4. To ascertain the level of satisfaction in using instant packed food products.

5. To offer suggestions on the basis of the results of the study.

\section{METHODOLOGY OF THE STUDY}

The study is based on primary data, the source of data lies with the respondents of the study.A sample size consists of 300 respondents, purchasing the instant packed food products. The sample size is selected by adapting convenient random sampling technique.

Tools for collection of data: Interview schedule is the major tool used for collecting the primary data from the respondents. The first nine questions deal with personnel information of the respondents and the other questions deal with the consumer preference and attitude towards purchase of select packed food products. The statistical package for social sciences (SPSS version 10.0) tools used for the purpose of analysis of this study such as:

a. Simple percentage analysis

b. Chi square Test

c. AnovaTest

Table 1. Showing gender of the respondents

\begin{tabular}{|l|c|c|c|}
\hline S. No & Gender & $\begin{array}{c}\text { No. of } \\
\text { Respondents }\end{array}$ & Percentage \\
\hline A & Male & 90 & 30 \\
\hline B & Female & 210 & 70 \\
\hline & Total & 300 & 100 \\
\hline
\end{tabular}

Source: Primary data

Figure 1: Gender of the respondents

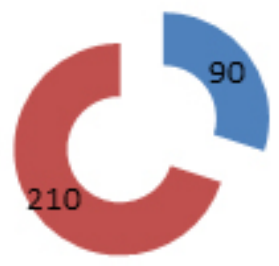

- Male

- Female

Limitation of the Study: The study is limited to area of cuddalore district only, due to time constrained only
300 respondents have been covered and as the method convienent sampling is used the findings cannot be generalized.

Table 2. Showing age group of the respondents

\begin{tabular}{|l|c|c|c|}
\hline S. No & Age & $\begin{array}{c}\text { No. of } \\
\text { Respondents }\end{array}$ & Percentage \\
\hline A & Below 25 Years & 30 & 10 \\
\hline B & $25-35$ years & 99 & 33 \\
\hline C & $35-45$ years & 69 & 23 \\
\hline D & $45-55$ years & 60 & 20 \\
\hline E & 55 years \&t above & 42 & 14 \\
\hline \multicolumn{2}{|c|}{ Total } & 300 & 100 \\
\hline \multicolumn{2}{|c|}{ Source: Primary data } \\
\hline
\end{tabular}

Figure 2: Age of the Respondents

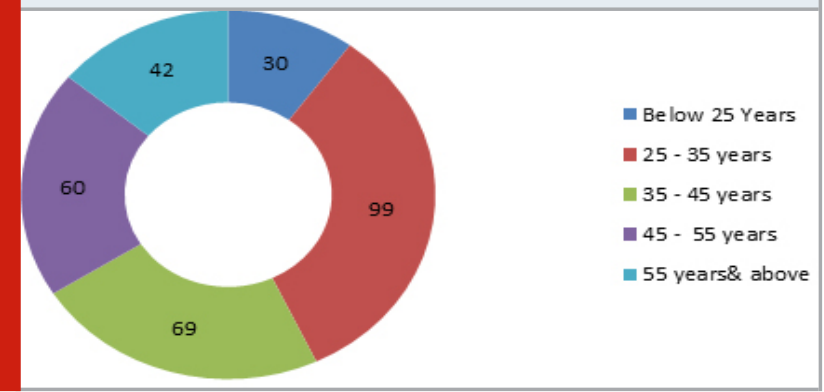

The above table shows that the gender of the respondents taken for the study, it given $70 \%$ of the respondents are female and 30\% of the respondents are male. The above table shows that the age group of the respondents. It is clearly given that $33 \%$ of the respondents are at the age group 25 - 35 years, 23\% of the respondents are falling under $35-45$ years, 20\% of the respondents are at the age group 45 - 55 years, $14 \%$ of the respondents are under the category of 55 years and above, 10\% of the respondents are below 25 years.

Hypothesis: The personal factors of the respondents have no significant influence over the sources of awareness of instant packed food products.

Inference: It is understood from the above table that the hypothesis is rejected in all the cases except one case viz., the gender of the respondents with source of awareness. It is concluded that there is significant relationship between the personal factors and source of awareness. Gender alone has no significant influence over the awareness of instant packed food products.

Hypothesis: The personal factors of the respondents have no significant influence over the sources of advertisements about instant packed food products.

Inference: It is understood from the above table that the hypothesis is accepted in the cases of gender and 
educational level and other cases the hypothesis is rejected. It is concluded that the gender, educational level has no significant influence over the sources of advertisements about instant food products. Other factors such as age, occupation, monthly income over the advertisements about instant food products.

Table 3. Showing the relationship between the personal factors of the respondents and sources of awareness

\begin{tabular}{|l|c|c|c|c|}
\hline S. No & Personal factors & Chi-square value & Table value & Inference \\
\hline A & Gender of the respondents & 2.52 & 9.49 & NS \\
\hline B & Age of the respondents & 111.93 & 26.30 & S \\
\hline C & Educational level & 44.26 & 21.00 & S \\
\hline D & Occupational status & 107.19 & 36.40 & S \\
\hline E & Monthly income & 79.55 & 26.30 & S \\
\hline F & Size of the family & 55.57 & 21.00 & S \\
\hline
\end{tabular}

S- Significant at 5\% level, NS- Not Significant

Table 4. Showing the relationship between the personal factors of the respondents and sources of advertisement

\begin{tabular}{|l|c|c|c|c|}
\hline \multirow{2}{*}{ S. No } & Personal factors & Chi-square value & Table value & Inference \\
\hline A & Gender of the respondents & 1.46 & 7.81 & NS \\
\hline B & Age of the respondents & 30.76 & 21.00 & S \\
\hline C & Educational level & 8.97 & 19.90 & NS \\
\hline D & Occupational status & 26.53 & 25.00 & S \\
\hline E & Monthly income & 25.09 & 12.60 & S \\
\hline F & Size of the family & 17.27 & 16.90 & S \\
\hline
\end{tabular}

S- Significant at 5\% level, NS- Not Significant

Hypothesis: There is no significance relationship between age group of the respondents and amounts spend for purchase.

Inference: The table value of is 2.6049. The calculated value of $\mathrm{F}$ is more than the table value. Hence we reject the hypothesis i.e., the age group of the respondents have significance influence over amount spend for purchase.
Hypothesis: There is no significance relationship between occupational status of the respondents and amount spent for purchase.

Inference: The table value of is 2.6049. The calculated value of $F$ is more than the table value. Hence we reject the hypothesis i.e., the occupational status of the respondents have significance influence over amount spend for purchase.

Table 5. Showing the relationship between the age group of the respondents and amount spend

\begin{tabular}{|l|c|c|c|}
\hline Source of variation & Sum of square & Degree of freedom & Mean Square \\
\hline Between groups & 16.58 & 3 & 5.53 \\
\hline Within groups & 429.67 & 296 & 1.45 \\
\hline Total & 446.25 & 299 & \\
\hline \multicolumn{2}{l|}{ Variance ratio of $\mathrm{F}=3.808$} \\
\hline
\end{tabular}

\section{Suggestions}

1. On the basis of results of the study, the following recommendations are made.
2. Unlike other products, hygienic aspect is more important for good. The packed food is liable for spoilage and perishable and hence adequate care is 
to be taken to ensure the hygienic aspect. This is a prominent issue in the preference and purchase of packed food products by the consumers.

3. It is found from the study that consumers give preference more to quality while buying packed food. For this purpose, better ingredients should be procured and added so that the required quality will be maintained.

4. It is also important that extra care is required before the food items are packed. The packaging should be good in the sense that the food packed is conducive for preservation and safety so that it is kept for long time without any problem.

5. On the basis of suggestions given by the respondents, it is recommended to the manufactures of packed food introduce more and more new varieties. This will keep the business to attract more number of consumers for their products.

6. It is also found from the study that the advertisements, given for packed food are not adequate. For any product, advertisement today is an essential activity to communicate and attract more consumers. Hence, it is suggested to the manufacturers and retailers of packed food to go for wide advertisements in the right media to enlarge the market for their products.

7. It is also found from the study that the products need lot of change and thus innovation is becoming necessary. The use of content, content measure and material mixing need to be changed for eg., it is suggested by the consumers that oil and chilli powder usage is to be considerably reduced while manufacturing packed food.

Table 5a. Showing the relationship between the occupational status of the
respondents and amount spend
\begin{tabular}{l|c|c|c|}
\hline Source of variation & Sum of square & Degree of freedom & Mean Square \\
\hline Between groups & 52.48 & 3 & 17.49 \\
\hline Within groups & 1385.24 & 296 & 4.68 \\
\hline Total & 1437.72 & 299 & \\
\hline Variance ratio of $\mathrm{F}=3.738$ & & \\
\hline
\end{tabular}

\section{CONCLUSION}

For any product, it is necessary to know why customers buy and why they do not buy. This type of information will be more useful to the manufacturer and that they can get such information from effective marketing research. Further it is always important to find out various factors that influence the purchasing attitude of the consumers so that they may go for producing required varieties with improvement in the quality, taste, packaging etc., Further, it becomes obligatory on the part of manufactures to explain to consumers as to why they should use the products and as to what benefit they will get in turn etc., as to will help manufactures to keep the existing customers more satisfied and to attract the new customers.

\section{REFERENCES}

Anitha, N. and Radhika, S., 2013. A study on consumer behavior towards instant food products in the modern era. JIMS8M: The Journal of Indian Management \&t Strategy, 18(4), pp.28-31.

Dhinakaran, D.P. and Kesavan, N., 2020. Exports and imports stagnation in India during COVID-19-A Review. GIS Business, 15(4), pp.1158-1177.

Ferdiana, A.M.K. and Darma, G.S., 2019. Understanding Fintech Through Go-Pay. International Journal of Innovative Science and Research Technology, 4(2), pp.257-260.

Mayakkannan, R., 2018. Impact of Buying Behaviour of
Consumers towards Instant Food Products in Chennai District. International Journal of Pure and Applied Mathematics, 119(12), pp.16279-16286.

Palaneeswari, T. and Vijayalakshmi, M.S., 2013. A study on consumer behaviour towards instant cooking food products in Sivakasi. ZENITH International Journal of Multidisciplinary Research, 3(2), pp.231-237.

Plikas, J.H., Plikas, H., Ntini, I. and Zattas, A.N., Piracy rates and software protection in the time of 2008 global economic crisis: Empirical analysis for Greece, Germany and England.

Ramasamy, A.K., Kalaivanan, G. and Sukumar, S., 2005. Consumer behaviour towards instant food products. Indian journal of marketing, 35(6).

Ranjeeth, S. and Latchoumi, T.P., 2020. Predicting Kids Malnutrition Using Multilayer Perceptron with Stochastic Gradient Descent. Rev. d'Intelligence Artif., 34(5), pp.631-636.

Swamy, M.B., Kumar, T.A. and Rao, K.S., 2012. Buying behaviour of consumers towards instant food products. International journal of Research and computational technology, 2(2), pp.975-5465.

Yookesh, T.L., Boobalan, E.D. and Latchoumi, T.P., 2020, March. Variational Iteration Method to Deal with Time Delay Differential Equations under Uncertainty Conditions. In 2020 International Conference on Emerging Smart Computing and Informatics (ESCI) (pp. 252-256). IEEE. 